\title{
Occipital Lymph Node
}

National Cancer Institute

\section{Source}

National Cancer Institute. Occipital Lymph Node. NCI Thesaurus. Code C98188.

A lymph node located in the back of the head adjacent to the trapezius muscle. 